The International Economy, Vol. 19, 2016

\title{
Who causes SMEs to suffer? An empirical analysis on the trade of SME products in Japan*
}

\author{
Sawako Maruyama ${ }^{\dagger}$ \\ Graduate School of Economics, Kobe University
}

\begin{abstract}
This paper aims to investigate the structure and the determinants of the trade of products manufactured by small- and medium-sized enterprises. For this purpose, a trade database for selected SME-based industries is prepared. Analyzing this database, the following three findings are obtained. First, firms in SME-based industries are facing a large inflow of imported goods, while the volume of their exports is relatively small. Secondly, the share of Asian countries is larger in the trade of SME products than overall trade. Thirdly, the gravity model can be applied for the trade of SME products. In some cases, distance and difference of income level tend to be more sensitive for SME products than overall trade. These results are consistent with the labor-intensive characteristics of SME products.
\end{abstract}

Key words: Trade, Gravity model, Small- and Medium-sized Enterprises (SMEs), Manufacturing

\section{Introduction}

Small- and medium-sized enterprises, SMEs, play important roles in the business activities in Japan. They dominate large-sized enterprises with more than 90 percent of total number of firms, and their production accounts for nearly half of the shipment value of manufacturing. Meanwhile, SMEs have been facing stiff competition since the 1980s. The rapid Yen appreciation after the Plaza Accord in 1985 lowered the competitiveness of Japanese SME products. In addition, the inflow of products from other Asian countries has precipitated a decline in domestic production of Japanese SMEs. Furthermore, the shrinking domestic market because of the aging population is enhancing these long-term trends. In contrast to the increased globalization of circumstances, globalization of the activities of Japanese SMEs is progressing slowly. An increasing number of SMEs engage in overseas activities, however,

Received 15 April 2014, Accepted 30 May 2016, Released online in J-STAGE as advance publication 1 August 2016

* The author is grateful to Kozo Kiyota, other participants at the JSIE Meeting and an anonymous referee for helpful comments and suggestions on an earlier draft.

$\uparrow$ Graduate School of Economics, Kobe University, 2-1 Rokkodai-cho, Nada-ku, Kobe, Japan 657-8501, E-mail:maruyama@econ.kobe-u.ac.jp 
Who causes SMEs to suffer? An empirical analysis on the trade of SME products in Japan

they are only a small part of total SMEs: only $2.8 \%$ of SMEs export their products abroad directly, and $1 \%$ of them make foreign direct investment, FDI (Small and Medium Enterprise Agency 2012, p. 71).

Globalization has changed business circumstances for Japanese SMEs, but to what extent have they changed? This paper attempts to estimate the volume of trade related to SMEs, since trade is the most relevant among overseas activities for SMEs. A database of SME products is prepared with concordance between Census of Manufactures by METI, the ministry of economy, trade and industry of Japan, and Trade Statistics by Ministry of Finance, MOF. This database makes it possible to analyze the characteristics and the trade structure of SME products. Moreover, this paper examines determinants of trade flow. How is the trade of SME products composed by industry and by region? What determines the trade flow of SME products ? Do those determinants affect trade of SME products differently from overall trade ? The aim of this paper is to answer these questions.

The rest of the paper is organized as follows. In the next section, we review literature which analyzes the overseas activities of SMEs in Japan. Section 3 explains the methodology of concordance between Census of Manufactures and Trade Statistics. In section 4, the determinants of trade of SME products are examined using the gravity model. The result of the analysis is summarized in section 5 .

\section{Literature}

Firm size is recognized as one of the important factors for internationalization. It has been employed as a determinant of overseas expansion of firms in many empirical analyses. However, most empirical literature has focused on large firms. Generally, SMEs engage less in overseas activities in comparison to large enterprises. One reason is that SMEs are lacking resources such as technology, human resources, and finance. Those resources are related to what Dunning called 'Ownership advantages' in his eclectic theory (see for example Dunning, 1977). Internationalized SMEs are a small portion of all SMEs. On the other hand, more SMEs are affected by the globalized economy regardless whether or not they engage in international business. Therefore, when we discuss globalization and SMEs, it is important to distinguish the following issues: the globalization of SMEs themselves and globalization of circumstances surrounding SMEs. We summarize the recent literature concerning these issues.

\subsection{Empirical analysis for SMEs}

With regard to the globalization of SMEs, a growing number of empirical analyses have been made using firm-level data. For example, an empirical analysis by Hollenstein (2005) reveals that firm size affects the probability and the degree of internationalization, especially to cross a threshold of internationalization. Similar results are presented in the survey of empirical analyses during late 1980s and 1990s by Coviello and McAuley (1999). They point out that firm size appears to affect the internationalization of firms. Meanwhile, they also mention some difficulties for empirical investigation. One of those difficulties is that internationalization is not explained using only one framework. A number of frameworks need to be integrated for the investigation. Another difficulty is biased samples of the manufacturing sector and focusing too much on country-specific factors. 


\section{S. Maruyama}

Similarly, most empirical analyses for Japanese SMEs focus on a specific industry or region. They often use questionnaires or interview surveys with qualitative factors, and there are only a small number of quantitative analyses for internationalization of Japanese SMEs. Urata and Kawai (2000) is one of those quantitative analyses. They examine the determinants of FDI location by Japanese SME. They use a dataset including both SMEs and large firms. Their empirical results show that SMEs are more sensitive to local conditions in making decision for FDI.

Some empirical analyses suggest that international SMEs are more productive and profitable than domestic SMEs, and this is in line with the results obtained from the analyses done on large enterprises. For example, an analysis of Small and Medium Enterprise Agency (2006) examines the effect of FDI on the performance of firms. They conclude that FDI by SMEs results in higher performance of domestic operations by shifting into the production of more sophisticated goods or operation of higher value-added fields ${ }^{1)}$. Kawai (2004) and Todo (2012) also examine the difference of performance between international and domestic SME with firm-level data. Kawai investigates the determinants of global strategies by SMEs and divides these into four stages: trade, outsourcing, subsidiary by joint venture, and whollyowned subsidiary. He concludes that activities of SMEs are more globalized when SMEs possess firm-specific assets such as R\&D investment or technology, introducing IT, or participating in a joint project. Todo focuses on the overseas outsourcing including both interfirm and intra-firm contracts. He finds that outsourcing to Asian firms improves the performance of headquarters in Japan.

These studies succeed in revealing the features of globalization by SMEs. However, the number of empirical analysis for SMEs is still fewer in comparison to large enterprises and the globalization of SMEs has not been examined sufficiently. Moreover, we have to pay attention to some limitations of analysis using firm-level data. Firstly, those studies investigate internationalized SMEs which account for only a small part of total SMEs. The vast majority of Japanese SMEs are not engaging in overseas activities, and the estimated result cannot be generalized to the whole of SMEs. Secondly, there is a potential of underestimation of trade since only direct trade is reported in the survey. A lot of manufacturing SMEs in Japan use trading companies for export, or trading companies independently export the products of manufacturing SMEs. Recently, there are studies emphasizing the importance of intermediaries on trade (see, for example, Ahn et al., 2011 and Bernard et al., 2011). Thirdly, imported goods competing with SME products are not observed in the survey which reports only direct import. To show the influence of trade on both international and domestic SMEs, it is necessary to estimate the trade effect at industry level.

\subsection{Import competition}

For SMEs in developed countries, import competition with products from developing countries is one of the major impacts induced by globalization. The effect of import competition on wages and employment has been investigated, although the effect is not limited to SMEs. Freeman and Katz (1991), Sachs and Shatz (1994) are examples of these types of analyses. They use industry-level data aggregated at 2-digit level of SIC. More detailed data are

1) Small and Medium Enterprise Agency (2006), pp. 88-91. 
Who causes SMEs to suffer? An empirical analysis on the trade of SME products in Japan

prepared by Feenstra (1996), and Feenstra et al. (2002). They offer a concordance dataset between industrial census using SIC code and trade statistics using HS code. This concordance enables us to test the impact of imports at a disaggregated level. Moreover, the 'import penetration ratio' can be calculated using shipment value and trade value by industry. In the Japanese case, a series of studies such as done by Tomiura and Uchida (2001), Tomiura (2003), and Tomiura (2004) are examples which prepare a connected database between 4-digit industrial code for Census of Manufactures and HS 9-digit code for Trade Statistics ${ }^{2}$.

These studies reveal the change of circumstances by globalization. They suggest that increasing import from developing countries affects domestic economy. This is true for Japanese SMEs which experienced rapid change of demand after the appreciation of the yen in 1980s. However, the effect of import has not been examined sufficiently due to a lack of appropriate data. For example, studies investigating entry and exit of SMEs as Doi (1992), Honjo and Harada (2006), Kawai and Urata (2002), Small and Medium Enterprise Agency (2002) do not include import or export as explanatory variables.

Therefore, this paper attempts to combine these two issues of the globalization of SMEs and globalization of circumstances surrounding SMEs using a dataset for trade of SME products.

\section{The methodology}

To prepare the dataset of trade of SME products, a couple of steps are required. In the first step, SME-based industries are selected in order to determine SME products. In the second step, trade goods corresponding to the selected SME-based industries are sorted out.

\subsection{Selection of SME-based industry}

To start analyzing the trade of products manufactured by SMEs, we have to define SME products and to distinguish them from others. In order to distinguish SME products, we select industries whose production is dominated by SMEs. According to the Act for Smalland Medium-sized Enterprises, SMEs are defined with the criteria of less than 300 employees or capital of 300 million yen for manufacturing. In this analysis, we employ a criterion of 300 employees. Census of Manufactures offers the aggregation of shipment value by firm size for the 3-digit code of Japan Standard Industrial Classification, JSIC ${ }^{3)}$. We aggregate shipment value of firms with less than 300 employees in 3-digit JSIC. When the aggregated value of an industry $i$ accounts for more than $70 \%$ of total shipment, the industry $i$ is regarded as an SME-based industry ${ }^{4}$. We use the average of SME shipment ratio from

2) In order to connect these different codes, an appendix table of Input-Output table for rearranging trade statistics is used. This appendix table is originally used when trade sector of I-O table is estimated. Detail of the methodology is described in the appendix of Tomiura and Uchida (2001).

3) JSIC code has changed since 2008, therefore data after 2008 is adapted to the old classification until 2007 using shipment value at 4-digit level. The number of enterprises for 2008-2009 is unavailable at 4-digit level. Thus, average number of enterprises is calculated for 2002-2007.

4) A criterion of $70 \%$ of total shipment is used when Small and Medium Enterprise Agency estimates trade value of SME products. Their method of estimation has a significant problem: they calculate shipment ratio using aggregation not by firm size but by plant size. It means that production of plants with less than 300 employees of large firms are included in the calculation of SME products. 


\section{S. Maruyama}

\section{2 to 2009.}

The result of calculation shows that 63 industries out of 150 in 3-digit code are classified as SME-based industry. The number of SMEs in those 63 industries is 99,796 on average during 2002-2007, and it accounts for 40.4\% of the total number of SMEs. The rest of SMEs are included in large-firm-based industries or mixed industries of both sizes. A number of light industries such as textile, apparel and leather are classified as SME-based industry. The largest SME-based industry concerning the number of firms is 'Fabricated constructional and architectural metal products' (JSIC 254) with 15,187 firms. In addition to this, industries related to intermediate goods or inputs for construction such as 'Sawing, planning mills and wood products' (131), 'Cement and its products' (222), 'Furniture' (141), and 'Sliding doors and screens' (143) have a large number of firms.

What are the features of SME-based industries? Figure 1 shows the relationship between SME shipment ratio and three industrial characteristics including average wage, capital equipment ratio, and labor distribution ratio. Each index of industrial characteristics is expressed as a ratio to total manufacturing. The first figure (a) shows that the average wage of SME-based industries tend to be $l^{\circ} w^{5}$. 53 out of 63 SME-based industries indicate lower values than the average of total manufacturing. The correlation coefficient between SME shipment ratio and average wage is -0.734 , which suggests a negative and strong relationship. The second figure (b) shows the relationship with capital equipment ratio ${ }^{6}$. A higher index indicates that an industry is more capital intensive. The correlation coefficient with SME shipment ratio is -0.345 , and this means that $\mathrm{SME}$-based industries tend to indicate a lower capital equipment ratio and be of labor-intensive nature. In addition, $51 \mathrm{SME}$-based industries show lower values of capital equipment ratio than average. The third figure, (c), shows a labor distribution ratio calculated as the ratio of total cash wage and salary to gross value added. An industry with high labor distribution ratio tends to be labor-intensive, and 55 SME-based industries indicate higher values than total manufacturing. The correlation with SME shipment ratio is positive with the value of 0.390. These facts suggest that most of SME-based industries are characterized as low-wage, labor-intensive industry.

\subsection{Concordance between SME-based industry and Trade Statistics}

At the next step to estimate trade value of SME products, it is necessary to use a concordance table between Census of Manufactures and TradeStatistics. In this analysis, the concordance table from the Input-Output Table (hereafter I-O table) by the Statistics Bureau is used as described in the analysis by Tomiura and Uchida (2001). The concordance table is a list prepared for the I-O table of base year 2005. We match 3-digit JSIC code of SME-based industries to 4-digit code of I-O table and select correspondent sectors on I-O table. From the concordance table, we obtain HS 9-digit trade goods included in selected 4-digit sectors on I-O table. Trade data of HS 9-digit from Trade Statistics is aggregated according to 3-digit $\mathrm{JSIC}^{7)}$. Trade statistics from 2001 to 2010 are connected,

5) Average wage is calculated as total cash wages and salaries per employee.

6) Capital equipment ratio is calculated as the value of tangible fixed assets per employee using available data for enterprises with more than 30 employees.

7) 3-digit JSIC code is not fully corresponding to 4-digit code of I-O table. Thus the correspondence between 3-digit JSIC code and 9-digit HS code is finally checked. 
Who causes SMEs to suffer? An empirical analysis on the trade of SME products in Japan

Figure 1: Characteristics of SME-based industries

(a)

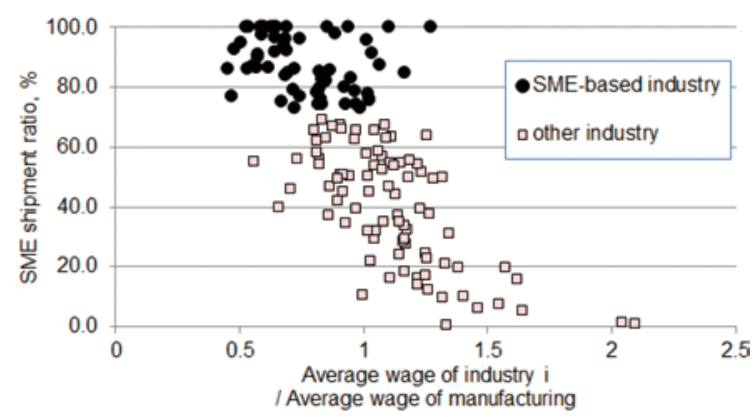

(b)

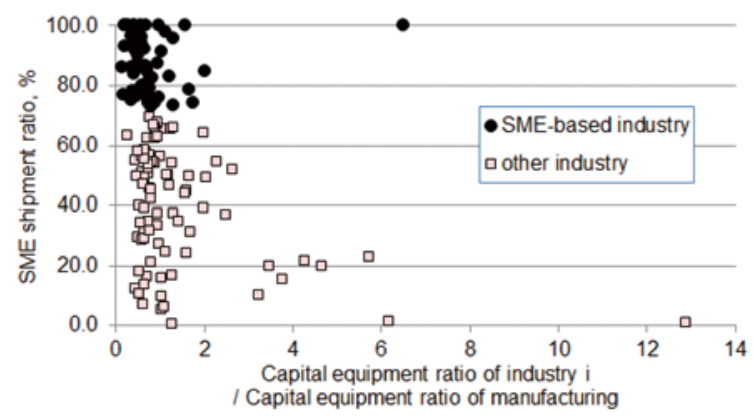

(c)

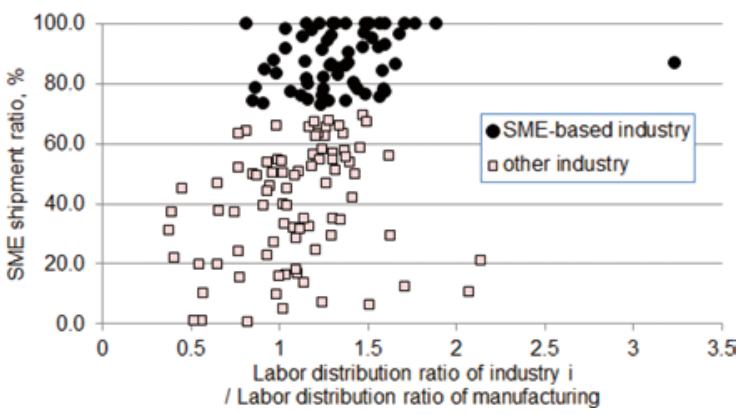

(Source) Own calculation.

(Notes) Average wage $($ mil. yen) $=$ Total cash wage and salary (mil. yen)

/ The number of employees

Capital equipment ratio $=$ Value of tangible fixed assets (end of the year, mil. yen)

/ The number of employees (enterprises with more than 30 employees)

Labor distribution ratio $=$ Total cash wage and salary (mil. yen)

/ Gross value added (mil. yen)

'Other industry' includes both large-firm based industries and mix-sized industries. 


\section{S. Maruyama}

Figure 2: Trade value of SME products and its ratio to overall trade
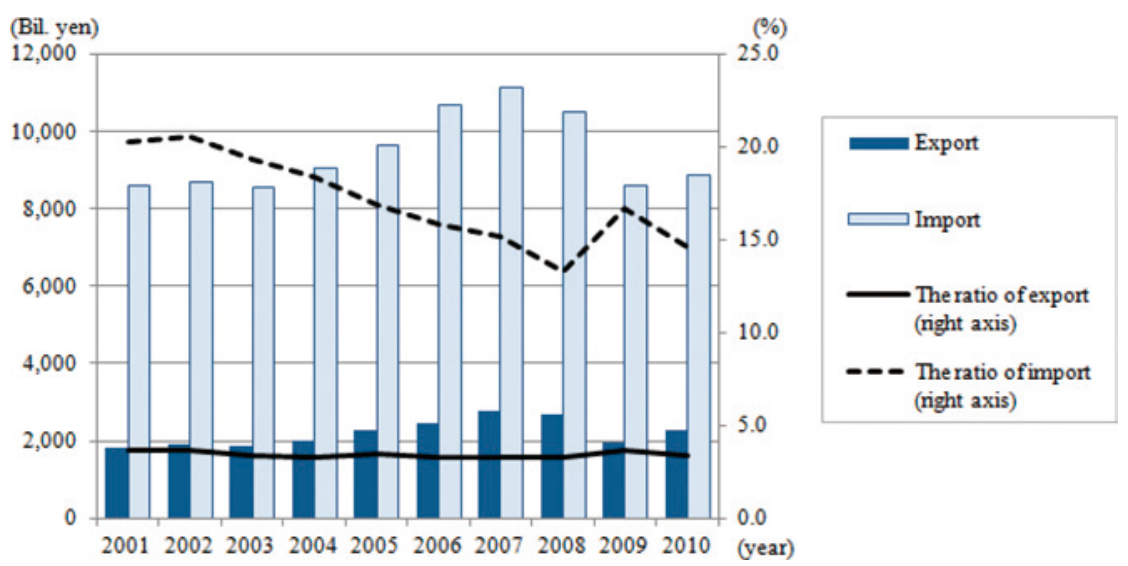

(Source) Own calculation.

reflecting the changes of HS 9-digit code. Three SME-based industries $(104,169,256)$ are excluded from the analysis because of the absence of corresponding trade goods, and one industry (242) is excluded on the grounds of being unable to distinguish from non-SMEbased industry (241) in Trade Statistics. The number of exported goods included in SME products is 1,865, while the number of imported goods is 3,595 in 2005.

Figure 2 shows aggregated value of and the ratio to total value of export/import. Both export and import values were highest in 2007, estimated 2,768 billion yen and 11,122 billion yen respectively. Aggregated import value of SME-products indicates about four times as large as export. The share of SME products to overall export accounts for around 3.5\% each year, while, concerning import, it accounts for around $20 \%$ of overall import. These results illustrate struggling SMEs which suffer from import competition on the one hand, and which cannot grow their export on the other hand. The latter is consistent with the suggestion of low export participation by Small and Medium Enterprise Agency (2012).

We can compare these trade values to domestic production using average value from 2002 to 2009 (Table 1). From export ratio to shipment, it is obvious that most of the SME-based industries show a low level of export. Only in four industries $(114,115,209,323)$, the export ratio to shipment indicates a value larger than 0.50 , that is to say, more than half amount of domestic production in these industries are exported. In addition, seven industries take values between 0.25 and 0.50 , which means that more than a quarter of the amount of production is exported. On the other hand, in fourteen industries the import ratio to shipment is larger than 1 , which means that the value of import exceeds the domestic production. Apparel industries $(121,122)$, of which domestic production is large, are one of those industries.

For the convenience of analysis, $59 \mathrm{SME}$-based industries are classified in 10 industrial groups based upon a 2-digit classification: Food and beverages, Textile, Apparel, Lumber and furniture, Paper and printing, Manufactured goods classified by materials, Leather, Ceramic, Fabricated metal, and Miscellaneous ${ }^{8)}$. To compare trade values among these industrial groups,

8) Respective industrial groups include following 3-digit industry: [Food and beverages] 92, 93, 96, 103, 
Who causes SMEs to suffer? An empirical analysis on the trade of SME products in Japan

Table 1: Trade ratio to shipment (average during 2002-2009)

\begin{tabular}{|c|c|c|c|}
\hline & JSIC code & $\begin{array}{l}\text { Export ratio } \\
\text { to shipment }\end{array}$ & $\begin{array}{l}\text { Import ratio } \\
\text { to shipment }\end{array}$ \\
\hline 92 & Seafood products & 0.036 & 0.392 \\
\hline 93 & Canned and preserved fruit and vegetable products & 0.011 & 0.545 \\
\hline 96 & Flour and grain mill products & 0.007 & 0.035 \\
\hline 103 & Tea and coffee & 0.011 & 0.072 \\
\hline 106 & Prepared animal foods and organic fertilizers & 0.007 & 0.133 \\
\hline 111 & Silk reeling plants & 0.341 & 5.983 \\
\hline 113 & Twisting and bulky yarns & 0.011 & 0.020 \\
\hline 114 & Woven fabric mills & 0.814 & 0.241 \\
\hline 115 & Knit fabrics mills & 0.527 & 0.091 \\
\hline 117 & Rope and netting & 0.109 & 0.202 \\
\hline 118 & Lace and other textile goods & 0.124 & 0.080 \\
\hline 119 & Miscellaneous textile mill products & 0.238 & 0.222 \\
\hline 121 & $\begin{array}{l}\text { Textile outer garments and shirts, including bonded fabrics and lace, except } \\
\text { Japanese style }\end{array}$ & 0.020 & 1.478 \\
\hline 122 & Knitted garments and shirts & 0.050 & 2.856 \\
\hline 123 & Underwear & 0.028 & 1.070 \\
\hline 124 & Japanese style apparel and "Tabi"-sock & 0.017 & 0.561 \\
\hline 125 & Other textile apparel and accessories & 0.036 & 1.025 \\
\hline 129 & Miscellaneous fabricated textile products & 0.023 & 0.538 \\
\hline 131 & Sawing, planning mills and wood products & 0.003 & 0.556 \\
\hline 132 & Millwork, plywood and prefabricated structural wood products & 0.001 & 0.232 \\
\hline 133 & Wooden, bamboo and rattan containers & 0.003 & 0.037 \\
\hline 139 & Miscellaneous manufacture of wood products, including bamboo and rattan & 0.017 & 0.632 \\
\hline 141 & Furniture & 0.058 & 0.307 \\
\hline 142 & Furniture for religious purposes & - & 0.277 \\
\hline 143 & Sliding doors and screens & 0.011 & 0.099 \\
\hline 151 & Pulp & 0.336 & 4.625 \\
\hline 154 & Paper products & 0.076 & 0.107 \\
\hline 162 & Plate making for printing & 0.000 & 0.000 \\
\hline 163 & Bookbinding and printed matter & 0.003 & 0.001 \\
\hline 171 & Chemical fertilizers & 0.056 & 0.364 \\
\hline 182 & Lubricating oils and greases (not made in petroleum refineries) & - & 0.003 \\
\hline 183 & Coke & 0.257 & 0.400 \\
\hline 189 & Miscellaneous petroleum and coal products & 0.398 & 0.864 \\
\hline 194 & Formed and reinforced plastic products & 0.055 & 0.028 \\
\hline 195 & Compounding plastic materials, including reclaimed plastics & 0.094 & 0.270 \\
\hline 202 & Rubber and plastic footwear and its findings & 0.024 & 2.598 \\
\hline
\end{tabular}

(Note) ' -' is denoted in industries lacking the corresponding code in either export or import. 
S. Maruyama

Table 1: Continued

\begin{tabular}{|c|c|c|c|}
\hline & JSIC code & $\begin{array}{l}\text { Export ratio } \\
\text { to shipment }\end{array}$ & $\begin{array}{l}\text { Import ratio } \\
\text { to shipment }\end{array}$ \\
\hline 209 & Miscellaneous rubber products & 0.639 & 0.354 \\
\hline 211 & Leather tanning and finishing & 0.199 & 0.260 \\
\hline 212 & Mechanical leather products, except gloves and mittens & 0.001 & 0.001 \\
\hline 213 & Cut stock and findings for boots and shoes & 0.109 & 1.153 \\
\hline 214 & Leather footwear & 0.007 & 0.615 \\
\hline 215 & Leather gloves and mittens & 0.003 & 1.227 \\
\hline 216 & Baggage & 0.055 & 4.844 \\
\hline 217 & Handbags and small leather cases & 0.007 & 1.211 \\
\hline 218 & Fur skins & 0.216 & 2.856 \\
\hline 219 & Miscellaneous leather products & 0.065 & 2.039 \\
\hline 222 & Cement and its products & 0.010 & 0.005 \\
\hline 227 & Abrasive products & 0.281 & 0.047 \\
\hline 228 & Aggregated and stone products & 0.001 & 0.177 \\
\hline 239 & Miscellaneous iron and steel & 0.005 & 0.038 \\
\hline 252 & Tableware (occidental type), cutlery, hand tools and hardware & 0.099 & 0.145 \\
\hline 254 & $\begin{array}{l}\text { Fabricated constructional and architectural metal products, including fabri- } \\
\text { cated plate work and sheet metal work }\end{array}$ & 0.009 & 0.031 \\
\hline 257 & Fabricated wire products & 0.208 & 0.155 \\
\hline 258 & Bolts, nuts, rivets, machine screws and wood screws & 0.232 & 0.076 \\
\hline 316 & Ophthalmic goods, including frames & 0.336 & 0.961 \\
\hline 321 & Precious metal products, including jewel & 0.380 & 1.356 \\
\hline 323 & Toys and sporting goods & 0.563 & 0.848 \\
\hline 326 & Lacquer ware & 0.002 & - \\
\hline 327 & $\begin{array}{l}\text { Sundry goods of straw, "Tatami" mats, umbrellas and other daily commodi- } \\
\text { ties }\end{array}$ & 0.093 & 0.417 \\
\hline
\end{tabular}

(Note) '-' is denoted in industries lacking the corresponding code in either export or import.

we use the average during 2001-2010. Among the 10 groups, textile is the only one group in which export exceeds import (Figure 3). In other groups the import value dominates the export value. The import value is especially large in the apparel industry; it is more than fifty times of the export value. These contrasting results are interesting; the apparel industry, which is located at the downstream of the value-chain shows opposite trade flow with textile industry at the upper stream. Meanwhile, the difference between the import and export value is not large among industrial groups which produce materials such as ceramic, fabricated metal, and manufactured goods classified by materials.

classified by materials] 171, 182, 183, 189, 194, 195, 202, 209 [Leather] 211, 212, 213, 214, 215, 216, 217, 218, 219 [Ceramic] 222, 227, 228 [Fabricated metal] 239, 252, 254, 257, 258 [Miscellaneous] 316, $321,323,326,327$. 
Who causes SMEs to suffer? An empirical analysis on the trade of SME products in Japan

Figure 3: Trade value by industrial group (average during 2001-2010)

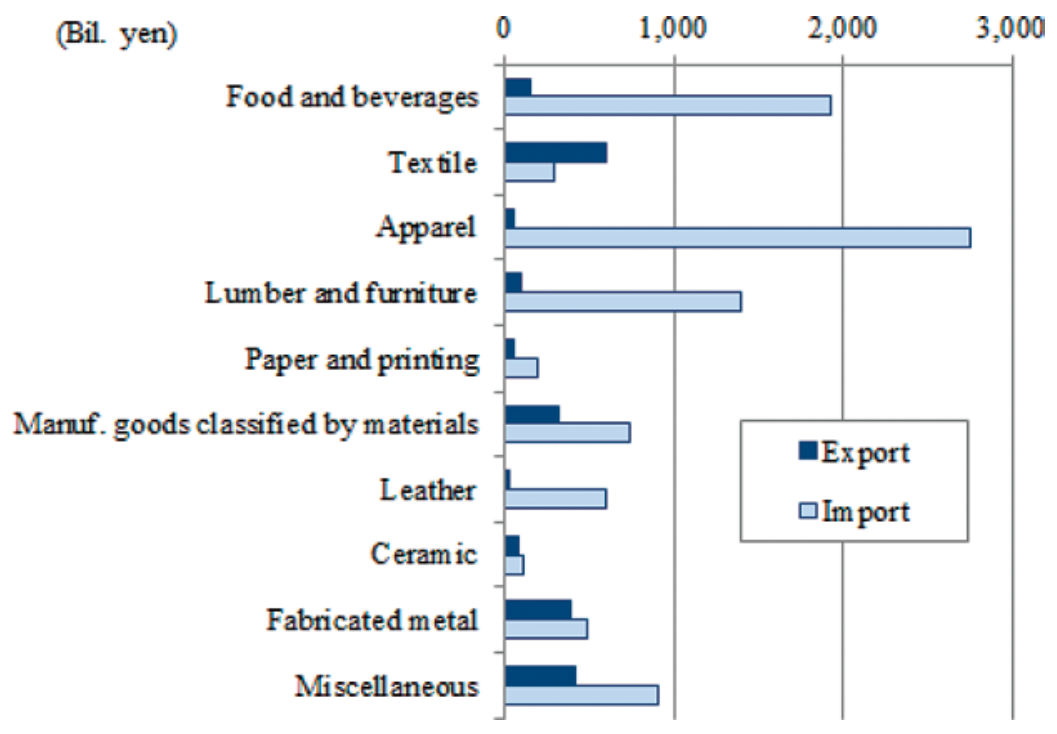

(Source) Own calculation.

\subsection{The trade structure of SME products}

For most of the SME products, the share of East and Southeast Asia is large in both export and import ${ }^{9)}$. This is obvious when it is compared with the regional composition of overall trade. Table 2 shows the number of goods which indicate higher share for East and Southeast Asia or for China in comparison to overall trade using the average during 2001-2010. Regarding East and Southeast Asia, 46 products for export and 44 products for import indicate higher share than overall trade. Focusing on trade with China, the share in 27 products for export and in 43 products for import is larger than the overall export respective import. At the same time, it means that the share of developed countries such as the US and the EU is smaller for SME products. These facts suggest that trade of SME products tends to be large with geographically approximate partners or developing countries.

\section{The determinants of trade of SME products}

\subsection{The framework of analysis}

In this section, we investigate determinants of trade structure of SME products ${ }^{10)}$. We examine the determinants of trade of SME products employing the gravity model. The gravity model is a model inspired from the law of universal gravitation, and it explains the bilateral trade flow. For variables it contains the economic size of countries of both origin and destina-

9) East and Southeast Asia includes China, NIEs (South Korea, Taiwan, Singapore and Hong Kong), and ASEAN4 (Thailand, Malaysia, Philippine and Indonesia.)

10) It must be noted that SME products do not cover all of the trade concerning SMEs; it only includes the industries dominated by SMEs. However, investigation for SMEs classified in large-size-based and mixed-size-based industries is beyond the scope of this paper. 
Table 2: Trade structure by region

\begin{tabular}{|c|c|c|c|}
\hline & & $\begin{array}{c}\text { East and } \\
\text { Southeast } \\
\text { Asia }\end{array}$ & China \\
\hline \multirow[t]{4}{*}{ (Export) } & The share in overall export & $46.4 \%$ & $14.3 \%$ \\
\hline & The number of the goods which indicate: & & \\
\hline & - higher share than overall export & 46 & 27 \\
\hline & - lower share than overall export & 11 & 30 \\
\hline \multirow[t]{4}{*}{ (Import) } & The share in overall import & $41.2 \%$ & $20.1 \%$ \\
\hline & The number of the goods which indicate: & & \\
\hline & - higher share than overall import & 44 & 43 \\
\hline & - lower share than overall import & 14 & 15 \\
\hline
\end{tabular}

(Source) Own calculation.

tion, and geographical distance. This model was used in the early study by Tinbergen (1962), and has been applied in a lot of empirical analyses of trade. The basic model is expressed as follows:

$$
E_{i j}=Y_{i}^{\beta_{1}} Y_{j}^{\beta_{2}} D_{i j}^{\beta_{3}}
$$

$E_{i j}$ is volume of export from country $i$ to country $j . Y_{i}$ is an economic size of export country and indicates the capacity of supplying. Generally, GDP is used as a proxy variable. The larger the GDP of the export country is, the more goods are supplied and traded. $Y_{j}$ is an economic size of import country which indicates the market size, and for this GDP is also used as a proxy variable. The larger the GDP of the import country is, the more goods are demanded and traded. In this paper, both export and import between Japan and each trade partner are tested as dependent variables. Geographical distance $D_{i j}$ indicates transportation cost and affects negatively upon trade flow.

In our estimation, three country-specific factors of trade preferential factor, difference of income level, and the exchange rates are added to expand the model ${ }^{11}$. The equation is expressed as follows using log-formation.

$$
\ln E_{i j}=\beta_{0}+\beta_{1} \ln Y_{i}+\beta_{2} \ln Y_{j}+\beta_{3} \ln D_{i j}+\beta_{4} P_{i j}+\beta_{5} y_{i j}+\beta_{6} x_{i j}
$$

Both coefficients of $\beta_{1}$ and $\beta_{2}$ are expected to be positive, and $\beta_{3}$ to be negative. Trade preferential factor $P_{i j}$ is a dummy variable for free trade agreement, FTA, in effect between Japan and trade partners. $\beta_{4}$ is expected to be positive. $y_{i j}$ is a variable indicating the difference of income level. $x_{i j}$ is exchange rate on a yen basis. Appreciation of the yen increases import (positive sign) and decreases export (negative sign).

Among these gravity factors, in which do the characteristics of SME products appear? The products of SMEs tend to be labor-intensive and low-wage goods, as shown in Figure 1. From these characteristics, two hypotheses are raised.

11) The gravity model has been expanded to include GDP per capita by Linnemann (1966) to test the effect of income level. 
Hypothesis 1: Import from the countries with lower income level tends to be larger for SME products in comparison with overall import.

As the factor proportion theory suggests, it is a developing country which holds a comparative advantage in labor-intensive industries. Japanese import of labor intensive goods including SME products is expected to be large from developing countries, as Japan is relatively capital abundant. Hypothesis 1 is tested using the difference of income level between Japan and each trade partner, $y_{i j}$. The effect of income difference on import, $\beta_{5}$ in equation (2), is expected to be positive, and the coefficient of SME products to be larger in an abusolute value than overall import. This means that SME products are imported more from the country with larger income difference. Meanwhile, the effect of income difference on export is not clear, since Japan has a comparative disadvantage in those labor-intensive industries.

The other hypothesis is regarding an effect of transport cost. For an importer, a transport cost is an additional cost to a price of imported goods. A large transport cost relative to the price diminishes the benefits of importing, and the importer tends to choose to import from geographically closer countries. This is more likely to happen for low-price, low value-added goods than high-price, high value-added goods, because the relative transport cost to valueadded is higher for low-price goods. Therefore, trade with distant countries is expected to be less for low-price goods. There are some discussions in recent literature with regard to the relationship between price/quality and distance. Baldwin and Harrigan (2011) show that highprice/high-quality goods are exported to distant markets, while low-price goods are not. Similarly, Hummels and Skiba (2004) empirically examine the 'Alchian-Allen effect', and show a positive relationship between prices and transportation costs.

SME products are assumed to be low-price, low value-added goods from their laborintensive characteristics. Therefore, trade with distant countries is expected to be smaller.

Hypothesis 2: Trade of SME products tend to be susceptible to transport costs.

The geographical distance is a proxy for transport cost and has a larger effect on SME products than overall trade ${ }^{12)}$. The coefficient of distance, $\beta_{3}$ in equation (2), is expected to be larger for SME products in comparison with overall trade.

\subsection{Data and the methods of estimation}

In regression analysis, the panel data of bilateral trade between Japan and each trade partner during 2001-2010 are employed. In order to make the characteristic of SME products clear, both trade value of SME products and overall trade are tested and compared. In addition, SME products are divided into 10 industrial groups shown in Figure 3 and tested. The bilateral trade value of SME products, both aggregated value and sorted values for ten industrial groups, are prepared as dependent variables. Overall export/import value used as a depen-

12) For apparel products, there is another reason. Dicken (2011) explains the importance of geographical proximity with a rapid rate of product turnover. He points that low-cost countries located close to the major consumer markets have a relative advantage in industries where time to delivery is critical. 


\section{S. Maruyama}

dent variable is obtained from Trade Statistics. These data are deflated using Corporate Goods Price Index 2005 by the Bank of Japan.

As shown in equation (2), a logarithm of trade value is used as a dependent variable. However, some cases include zero observations which are impossible to transform into a logarithm. We employ three methods suitable for data with zero observation. The first method is to use a logarithm of the value added one to each trade value, $\ln \left(E_{i j}+1\right)$. Then, it is possible to employ panel regression with the random effects which is used most commonly in the test of the gravity model. The second method is Tobit regression with random effects. Tobit model is employed when a dependent variable is truncated and includes a lot of zero observations. Also with this method, a logarithm of trade value plus one is used. The third method is negative binomial regression with fixed/random effects. Negative binomial model (hereafter NB model) is employed when a dependent variable is count data and it also allows the dependent variable to include zero observation ${ }^{13)}$. In regression of the NB model, dependent variable is expressed in level, $E_{i j}$, and independent variables are expressed with linear relationship as equation (2).

In addition to fixed or random effects, all regressions include the year dummy. Because either exporter or importer is fixed to Japan, Japanese GDP works the same way as a constant term. Therefore, Japanese GDP is omitted from the independent variables. These estimating methods using fixed or random effects and year dummies are consistent with the recent discussion of econometric specification for gravity model to avoid biased estimation due to omitted variables such as price effects ${ }^{14)}$.

GDP data is obtained from the National Accounts database of the United Nations. Real GDP in national currency of each trade partner is transformed to a yen-basis using exchange

13) NB model is a model which relaxes the variance assumption of the Poisson model. In the NB model, the negative binomial density is expressed as follows:

$$
f(y \mid \mu, \alpha)=\frac{\Gamma\left(y+\alpha^{-1}\right)}{\Gamma(y+1) \Gamma\left(\alpha^{-1}\right)}\left(\frac{\alpha^{-1}}{\alpha^{-1}+\mu}\right)^{\alpha^{-1}}\left(\frac{\mu}{\alpha^{-1}+\mu}\right)^{y}
$$

where mean of $y_{i}$ is $\mu$, and variance is $\mu(1+\alpha \mu)$. For the panel estimation using fixed effects for $n$ individuals, mean is expressed using $\delta_{i}=\ln n_{i}$ :

$$
E\left[y_{i t} \mid x_{i t}^{\prime}, n_{i}\right]=\exp \left(\delta_{i}+x_{i t}^{\prime} \beta\right)
$$

For details of NB model and panel NB model, see Cameron and Trivedi (1998), Cameron and Trivedi (2005).

14) For detail of the price effects and introduction of multilateral resistance terms, see Feenstra (2016). Introduction of country-specific effect (fixed or random effect) is useful for avoiding misspecification. Stack (2009) recommends a generalized gravity model with a full interaction effects which includes three main effects and three interactions. Export flows at year $t$ from country $i$ to country $j$ are expressed as follows:

$$
E X P_{i j}^{t}=\alpha_{0}+\beta^{\prime} X_{i j}^{t}+\theta^{t}+\gamma_{i}+\omega_{j}+\gamma \omega_{i j}+\gamma \theta_{i}^{t}+\omega \theta_{j}^{t}+\varepsilon_{i j}^{t},
$$

where $X^{t}$ denotes independent variables. Main effects involve time dummies $\theta^{t}$, exporter-specific dummies $\gamma_{i}$, and importer-specific dummies $\omega_{j}$. Interactions involve exporter-importer dummies $\gamma \omega_{i j}$, exporter-time dummies $\gamma \theta_{i}^{t}$, and importer-time dummies $\omega \theta_{j}^{t}$. $\varepsilon_{i j}^{t}$ is an error term. In our model, either exporter or importer is fixed to Japan. In a case of $j$ fixed to Japan, country-specific effects $\omega_{j}$ is contained in a constant term. Similarly, interactions $\gamma \omega_{i j}$ and $\omega \theta_{j}^{t}$ are omitted, and $\gamma \theta_{i}^{t}$ is contained in $\varepsilon_{i j}^{t}=$ $\varepsilon_{i}^{t}$. In short, available effects are time dummies and partner-specific dummies. 
Who causes SMEs to suffer? An empirical analysis on the trade of SME products in Japan

Table 3: Summary statistics

\begin{tabular}{|c|c|c|c|c|c|}
\hline (Export) & $n=1930$ & & & & \\
\hline Variable & Definition & Mean & Std. Dev. & Min & Max \\
\hline PARTRGDP & GDP of trade pertner (destination) & 28.03896 & 2.551129 & 18.70462 & 34.97562 \\
\hline DISTANCE & Distance between the capitals & 9.150367 & 0.4343674 & 7.057898 & 9.829572 \\
\hline$D I F G D P P C$ & Difference of GDP per capita & 2.378161 & 1.711203 & -1.030336 & 11.85857 \\
\hline EXCHRATE & Exchange rate & $6.19 \mathrm{e}-08$ & 1.000259 & -2.60295 & 2.61194 \\
\hline \multicolumn{6}{|c|}{ (Import) $\quad n=1890$} \\
\hline Variable & Definition & Mean & Std. Dev. & Min & Max \\
\hline PARTRGDP & GDP of trade pertner (source) & 28.08149 & 2.557016 & 18.70462 & 34.97562 \\
\hline DISTANCE & Distance between the capitals & 9.14526 & 0.4370898 & 7.057898 & 9.829572 \\
\hline$D I F G D P P C$ & Difference of GDP per capita & 2.381252 & 1.705538 & -1.030336 & 11.85857 \\
\hline EXCHRATE & Exchange rate & $-2.17 \mathrm{e}-06$ & 1.000268 & -2.6029 & 2.6119 \\
\hline
\end{tabular}

Table 4: Correlation matrix

(Export)

\begin{tabular}{l|ccccc}
\hline & PARTRGDP & DISTANCE & DIFGDPPC & EXCHRATE & FTADUMMY \\
\hline PARTRGDP & 1.0000 & & & & \\
DISTANCE & -0.1020 & 1.0000 & & & \\
DIFGDPPC & -0.4484 & 0.0332 & 1.0000 & & \\
EXCHRATE & -0.0517 & 0.0000 & 0.0871 & 1.0000 & \\
FTADUMMY & 0.1385 & -0.1138 & -0.0740 & 0.0533 & 1.0000 \\
\hline \multicolumn{1}{c}{ (Import) } & & & & & \\
\hline \multicolumn{7}{c}{ PARTRGDP } & DISTANCE & DIFGDPPC & EXCHRATE & FTADUMMY \\
\hline PARTRGDP & 1.0000 & & & & \\
DISTANCE & -0.0940 & 1.0000 & & & \\
DIFGDPPC & -0.4578 & 0.0373 & 1.0000 & & \\
EXCHRATE & -0.0519 & 0.0000 & 0.0880 & 1.0000 & \\
FTADUMMY & 0.1373 & -0.1127 & -0.0753 & 0.0538 & 1.0000 \\
\hline
\end{tabular}

rates crossrates prepared by UNCTAD. As a proxy of transport cost, direct distance between the capital cities is used ${ }^{15)}$. All of these variables are transformed to a logarithm. The difference of income level is calculated as a logarithm of Japanese GDP per capita minus a logarithm of GDP per capita of a trade partner.

The exchange rates are also introduced as an independent variable. We are interested in the volatility of currency, not in the cross-country difference, therefore normalized exchange rates for each trade partner are employed. A larger value means the appreciation of the yen,

15) Distance is calculated using a calculator of the website of Geospatial Information Authority of Japan and the latitude and longitude of each capital city. 


\section{S. Maruyama}

while a smaller value means depreciation. FTA dummy variable is introduced as a variable which indicates one since the year when FTA enters into effect. In case that FTA goes into effect during the last quarter of the year, FTA dummy starts to take one from the following year. Summary statistics and correlation matrix of variables are listed in Table 3 and 4 respectively.

\subsection{The results of estimation: comparison between SME products and overall trade}

First, we compare the estimation results between SME products and overall trade. We estimate determinants of trade using panel data of 193 countries for export and 189 countries for import. The results of estimation for export and import are shown in Table 5 and 6 respectively. Hausman test for NB regression supports the estimation with fixed effects, therefore the results of NB regression with random effects are omitted.

As for fundamental variables of the gravity model, effects of PARTRGDP and DIS$T A N C E$ are clear; coefficients of them show expected signs and are statistically significant for both export and import by any method. We can conclude that the gravity model is applicable for the trade of SME products; the longer the distance with a trade partner, the less SME products are traded.

Coefficients of DIFGDPPC vary for methods. For export, panel and Tobit regression show positive results, while the results of NB regression are negative-signed and significant. For import, all coefficients are positive-signed, and only estimation using NB regression

Table 5: Determinants of Export

\begin{tabular}{lcccccc}
\hline & \multicolumn{2}{c}{ Panel: random effects } & \multicolumn{2}{c}{ Tobit: random effects } & Negative binomial: fixed effects \\
\cline { 2 - 7 } & $\begin{array}{l}\text { Overall } \\
\text { export }\end{array}$ & $\begin{array}{c}\text { SME } \\
\text { products }\end{array}$ & $\begin{array}{c}\text { Overall } \\
\text { export }\end{array}$ & $\begin{array}{c}\text { SME } \\
\text { products }\end{array}$ & $\begin{array}{c}\text { Overall } \\
\text { export }\end{array}$ & $\begin{array}{c}\text { SME } \\
\text { products }\end{array}$ \\
\hline PARTRGDP & 0.768 & 1.116 & 0.767 & 1.115 & 0.164 & 0.511 \\
& $(19.409)^{* * *}$ & $(17.674)^{* * *}$ & $(18.909)^{* * *}$ & $(17.516)^{* * *}$ & $(11.355)^{* * *}$ & $(34.023)^{* * *}$ \\
DISTANCE & -1.314 & -2.447 & -1.316 & -2.448 & 0.314 & -1.150 \\
& $(-6.278)^{* * *}$ & $(-7.310)^{* * *}$ & $(-6.149)^{* * *}$ & $(-7.264)^{* * *}$ & $(3.738)^{* * *}$ & $(-13.427)^{* * *}$ \\
DIFGDPPC & 0.062 & 0.290 & 0.068 & 0.294 & -0.108 & -0.115 \\
& $(1.116)$ & $(3.334)^{* * *}$ & $(1.179)$ & $(3.297)^{* * *}$ & $(-5.364)^{* * *}$ & $(-5.292)^{* * *}$ \\
EXCHRATE & 0.132 & 0.094 & 0.130 & 0.093 & 0.046 & 0.079 \\
& $(3.323)^{* * *}$ & $(1.739)^{*}$ & $(3.287)^{* * *}$ & $(1.724)^{*}$ & $(1.958)^{*}$ & $(5.671)^{* * *}$ \\
FTADUMMY & 0.585 & 0.435 & 0.576 & 0.431 & 0.473 & 0.195 \\
Constant & $(2.163)^{* *}$ & $(1.174)$ & $(2.135)^{* * *}$ & $(1.168)$ & $(3.441)^{* * *}$ & $(3.018)^{* * *}$ \\
& 6.117 & 2.099 & 6.160 & 2.122 & -7.398 & -3.152 \\
No. of obs. & $(2.613)^{* * *}$ & $(0.561)$ & $(2.573)^{* *}$ & $(0.563)$ & $(-7.969)^{* * *}$ & $(-3.266)^{* * *}$ \\
Wald-chi2 & 1930 & 1930 & 1930 & 1930 & 1930 & 1930 \\
loglikelihood & 667.773 & 488.522 & 623.593 & 473.397 & 321.452 & 2773.810 \\
Hausman & & & -3333.2162 & -3952.2924 & -30396.237 & -21970.602 \\
\hline
\end{tabular}

(Note) The numbers in parentheses are $\mathrm{z}$-values. $*, * *, * * *$ indicate significant level at $10 \%$, $5 \%$, and $1 \%$ respectively.

Negative binomial regression is tested using Stata command 'xtnbreg' with FE option. Fixed effects model is chosen from the result of Hausman test for FE vs RE. 
Who causes SMEs to suffer? An empirical analysis on the trade of SME products in Japan

Table 6: Determinants of Import

\begin{tabular}{|c|c|c|c|c|c|c|}
\hline & \multicolumn{2}{|c|}{ Panel: random effects } & \multicolumn{2}{|c|}{ Tobit: random effects } & \multicolumn{2}{|c|}{ Negative binomial: fixed effects } \\
\hline & $\begin{array}{l}\text { Overall } \\
\text { import }\end{array}$ & $\begin{array}{l}\text { SME } \\
\text { products }\end{array}$ & $\begin{array}{l}\text { Overall } \\
\text { import }\end{array}$ & $\begin{array}{l}\text { SME } \\
\text { products }\end{array}$ & $\begin{array}{l}\text { Overall } \\
\text { import }\end{array}$ & $\begin{array}{l}\text { SME } \\
\text { products }\end{array}$ \\
\hline PARTRGDP & $\begin{array}{c}1.166 \\
(17.448)^{* * *}\end{array}$ & $\begin{array}{c}1.225 \\
(11.647)^{* * *}\end{array}$ & $\begin{array}{c}1.160 \\
(16.649)^{* * *}\end{array}$ & $\begin{array}{c}1.217 \\
(11.148)^{* * *}\end{array}$ & $\begin{array}{c}0.460 \\
(33.139)^{* * *}\end{array}$ & $\begin{array}{c}0.511 \\
(31.664)^{* * *}\end{array}$ \\
\hline DISTANCE & $\begin{array}{l}-2.173 \\
(-6.166)^{* * *}\end{array}$ & $\begin{array}{l}-2.549 \\
(-4.590)^{* * *}\end{array}$ & $\begin{array}{l}-2.180 \\
(-5.948)^{* * *}\end{array}$ & $\begin{array}{l}-2.557 \\
(-4.459)^{* * *}\end{array}$ & $\begin{array}{c}-1.345 \\
(-16.386)^{* * *}\end{array}$ & $\begin{array}{c}-1.082 \\
(-13.437)^{* * *}\end{array}$ \\
\hline DIFGDPPC & $\begin{array}{l}0.336 \\
(3.758)^{* * *}\end{array}$ & $\begin{array}{l}0.577 \\
(4.126)^{* * *}\end{array}$ & $\begin{array}{c}0.355 \\
(3.735)^{* * *}\end{array}$ & $\begin{array}{l}0.600 \\
(4.077)^{* * *}\end{array}$ & $\begin{array}{l}-0.090 \\
(-4.439)^{* * *}\end{array}$ & $\begin{array}{c}0.036 \\
(1.604)\end{array}$ \\
\hline EXCHRATE & $\begin{array}{l}0.128 \\
(2.780)^{* * *}\end{array}$ & $\begin{array}{c}0.046 \\
(0.657)\end{array}$ & $\begin{array}{l}0.123 \\
(2.655)^{* * *}\end{array}$ & $\begin{array}{c}0.039 \\
(0.559)\end{array}$ & $\begin{array}{l}0.063 \\
(5.069)^{* * *}\end{array}$ & $\begin{array}{c}0.075 \\
(3.852)^{* * *}\end{array}$ \\
\hline FTADUMMY & $\begin{array}{c}0.270 \\
(0.872)\end{array}$ & $\begin{array}{c}0.230 \\
(0.486)\end{array}$ & $\begin{array}{c}0.259 \\
(0.840)\end{array}$ & $\begin{array}{c}0.223 \\
(0.474)\end{array}$ & $\begin{array}{c}0.045 \\
(0.753)\end{array}$ & $\begin{array}{l}0.208 \\
(2.140)^{* *}\end{array}$ \\
\hline Constant & $\begin{array}{c}1.587 \\
(0.404)\end{array}$ & $\begin{array}{c}0.053 \\
(0.009)\end{array}$ & $\begin{array}{c}1.748 \\
(0.427)\end{array}$ & $\begin{array}{c}0.298 \\
(0.047)\end{array}$ & $\begin{array}{c}0.507 \\
(0.579)\end{array}$ & $\begin{array}{l}-4.549 \\
(-5.118)^{* * *}\end{array}$ \\
\hline No.of obs. & 1890 & 1890 & 1890 & 1890 & 1890 & 1890 \\
\hline Wald-chi2 & 441.085 & 217.579 & 386.361 & 198.939 & 1749.343 & 1450.631 \\
\hline loglikelihood & & & -3558.815 & -4362.086 & -27346.299 & -22931.599 \\
\hline Hausman & & & & & -4457.99 & -152.37 \\
\hline
\end{tabular}

(Note) The numbers in parentheses are $\mathrm{z}$-values. ${ }^{*}, * *, * * *$ indicate significant level at $10 \%, 5 \%$, and $1 \%$ respectively.

Negative binomial regression is tested using Stata command 'xtnbreg' with FE option.

Fixed effects model is chosen from the result of Hausman test for FE vs RE.

are insignificant concerning SME products. Trade preferential factor FTADUMMY is with a positive sign as expected in both export and import. However, for SME products, only the results using NB model are significant. Concerning EXCHRATE, all coefficients are positive for both results of export and import, although positive signs are expected only for import. For the sum of SME import, only the results using NB model are significant. These results suggest that to some extent effects of country-specific factors may depends on the estimating methods.

How about two hypotheses for the characteristics of SME products? From the first hypothesis concerning DIFGDPPC, we expect that the coefficient of import of SME products shows a larger value than that of overall import. In Table 6 , the results of panel regression and Tobit model with random effects support the hypothesis. For the result using NB model, the test for overall import results in an unexpected negative sign, while SME products hold a positive sign. From these results, it is concluded that the import of SME products tends to be larger with developing countries.

The second hypothesis is concerning the effect of DISTANCE. We expect that the absolute value of the coefficient of SME products is larger than overall export/import. In the result of export in Table 5, coefficients of SME products exceed those of overall export in panel regression and the Tobit model. In NB model it is impossible to compare the strength of effect, because the signs are opposite between overall export and SME products. The results are similar in the case of import. Coefficients using panel regression and Tobit regression with random effects support the hypothesis 2 . However, the coefficient of overall import is larger 


\section{S. Maruyama}

Table 7: Export, Tobit regression: random effects

\begin{tabular}{|c|c|c|c|c|c|}
\hline & $\begin{array}{l}\text { Food and } \\
\text { Beverages }\end{array}$ & Textile & Apparel & $\begin{array}{l}\text { Lumber and } \\
\text { Furniture }\end{array}$ & $\begin{array}{c}\text { Paper and } \\
\text { Printing }\end{array}$ \\
\hline PARTRGDP & $\begin{array}{l}1.040 \\
(9.760)^{* * *}\end{array}$ & $\begin{array}{c}1.355 \\
(13.791)^{* * *}\end{array}$ & $\begin{array}{c}1.191 \\
(16.475)^{* * *}\end{array}$ & $\begin{array}{c}1.333 \\
(18.310)^{* * *}\end{array}$ & $\begin{array}{c}1.339 \\
(18.134)^{* * *}\end{array}$ \\
\hline DISTANCE & $\begin{array}{l}-3.387 \\
(-6.010)^{* * *}\end{array}$ & $\begin{array}{l}-3.961 \\
(-7.604)^{* * *}\end{array}$ & $\begin{array}{l}-3.665 \\
(-9.626)^{* * *}\end{array}$ & $\begin{array}{l}-3.581 \\
(-9.324)^{* * *}\end{array}$ & $\begin{array}{l}-3.142 \\
(-8.065)^{* * *}\end{array}$ \\
\hline$D I F G D P P C$ & $\begin{array}{l}-0.100 \\
(-0.664)\end{array}$ & $\begin{array}{l}0.233 \\
(1.737)^{*}\end{array}$ & $\begin{array}{r}0.136 \\
(1.320)\end{array}$ & $\begin{array}{l}0.176 \\
(1.673)^{*}\end{array}$ & $\begin{array}{l}0.239 \\
(2.279)^{* *}\end{array}$ \\
\hline EXCHRATE & $\begin{array}{c}0.088 \\
(0.888)\end{array}$ & $\begin{array}{r}0.053 \\
(0.746)\end{array}$ & $\begin{array}{r}0.062 \\
(0.836)\end{array}$ & $\begin{array}{c}0.085 \\
(1.017)\end{array}$ & $\begin{array}{c}0.104 \\
(1.557)\end{array}$ \\
\hline FTADUMMY & $\begin{array}{c}0.946 \\
(1.399)\end{array}$ & $\begin{array}{r}0.288 \\
(0.598)\end{array}$ & $\begin{array}{r}0.228 \\
(0.452)\end{array}$ & $\begin{array}{c}0.804 \\
(1.407)\end{array}$ & $\begin{array}{c}0.026 \\
(0.056)\end{array}$ \\
\hline Constant & $\begin{array}{c}8.249 \\
(1.309)\end{array}$ & $\begin{array}{r}6.224 \\
(1.069)\end{array}$ & $\begin{array}{r}5.755 \\
(1.350)\end{array}$ & $\begin{array}{c}0.770 \\
(0.179)\end{array}$ & $\begin{array}{c}-3.779 \\
(-0.867)\end{array}$ \\
\hline No. of obs. & 1930 & 1930 & 1930 & 1930 & 1930 \\
\hline Wald-chi2 & 207.616 & 346.889 & 487.945 & 571.072 & 515.478 \\
\hline \multirow[t]{2}{*}{ loglikelihood } & -5111.510 & -4485.459 & -4539.320 & -4773.257 & -4352.194 \\
\hline & $\begin{array}{c}\text { Manuf. Goods } \\
\text { by Material }\end{array}$ & Leather & Ceramic & $\begin{array}{l}\text { Fabricated } \\
\text { Metal }\end{array}$ & Miscellaneous \\
\hline PARTRGDP & $\begin{array}{c}1.325 \\
(16.350)^{* * *}\end{array}$ & $\begin{array}{c}1.068 \\
(14.847)^{* * *}\end{array}$ & $\begin{array}{c}1.311 \\
(14.085)^{* * *}\end{array}$ & $\begin{array}{c}1.255 \\
(15.777)^{* * *}\end{array}$ & $\begin{array}{c}1.123 \\
(12.469)^{* * *}\end{array}$ \\
\hline DISTANCE & $\begin{array}{l}-2.189 \\
(-5.090) * * *\end{array}$ & $\begin{array}{l}-3.605 \\
(-9.486) * * *\end{array}$ & $\begin{array}{l}-3.519 \\
(-7.149)^{* * *}\end{array}$ & $\begin{array}{l}-3.011 \\
(-7.151)^{* * *}\end{array}$ & $\begin{array}{l}-3.760 \\
(-7.930)^{* * *}\end{array}$ \\
\hline$D I F G D P P C$ & $\begin{array}{l}0.370 \\
(3.301)^{* * *}\end{array}$ & $\begin{array}{c}0.104 \\
(1.022)\end{array}$ & $\begin{array}{c}0.149 \\
(1.141)\end{array}$ & $\begin{array}{l}0.283 \\
(2.556)^{* *}\end{array}$ & $\begin{array}{c}-0.029 \\
(-0.223)\end{array}$ \\
\hline EXCHRATE & $\begin{array}{c}0.083 \\
(1.371)\end{array}$ & $\begin{array}{l}0.184 \\
(2.897)^{* * *}\end{array}$ & $\begin{array}{c}-0.078 \\
(-0.994)\end{array}$ & $\begin{array}{c}-0.034 \\
(-0.506)\end{array}$ & $\begin{array}{l}0.339 \\
(4.983)^{* * *}\end{array}$ \\
\hline FTADUMMY & $\begin{array}{c}0.291 \\
(0.706)\end{array}$ & $\begin{array}{c}-0.029 \\
(-0.066)\end{array}$ & $\begin{array}{c}0.375 \\
(0.702)\end{array}$ & $\begin{array}{c}0.183 \\
(0.394)\end{array}$ & $\begin{array}{c}0.403 \\
(0.882)\end{array}$ \\
\hline Constant & $\begin{array}{c}-8.720 \\
(-1.815)^{*}\end{array}$ & $\begin{array}{c}6.411 \\
(1.508)\end{array}$ & $\begin{array}{c}0.036 \\
(0.006)\end{array}$ & $\begin{array}{c}1.573 \\
(0.334)\end{array}$ & $\begin{array}{l}10.571 \\
(1.992)^{* *}\end{array}$ \\
\hline No. of obs. & 1930 & 1930 & 1930 & 1930 & 1930 \\
\hline Wald-chi2 & 381.472 & 419.628 & 404.764 & 401.029 & 309.147 \\
\hline loglikelihood & -4180.990 & -4250.658 & -4660.888 & -4393.114 & -4379.658 \\
\hline
\end{tabular}

(Note) The numbers in parentheses are $\mathrm{z}$-values. *, **, *** indicate significant level at $10 \%$, $5 \%$, and $1 \%$ respectively.

than SME products in NB model.

As a whole, hypothesis 1 is supported from our regression results. Hypothesis 2 is partly supported, and it depends on the method of regression.

\subsection{The results by industrial group}

We additionally estimate determinants of sorted SME products by 10 industrial groups to check whether the gravity factors and two hypotheses are supported at disaggregated level. Tobit model with random effects and NB model with fixed effects, which are compara- 
Who causes SMEs to suffer? An empirical analysis on the trade of SME products in Japan

Table 8: Export, Negative binomial regression: fixed effects

\begin{tabular}{|c|c|c|c|c|c|}
\hline & $\begin{array}{l}\text { Food and } \\
\text { Beverages }\end{array}$ & Textile & Apparel & $\begin{array}{l}\text { Lumber and } \\
\text { Furniture }\end{array}$ & $\begin{array}{l}\text { Paper and } \\
\text { Printing }\end{array}$ \\
\hline PARTRGDP & $\begin{array}{c}0.406 \\
(17.746)^{* * *}\end{array}$ & $\begin{array}{c}0.593 \\
(28.693)^{* * *}\end{array}$ & $\begin{array}{c}0.586 \\
(27.435)^{* * *}\end{array}$ & $\begin{array}{c}0.622 \\
(28.139)^{* * *}\end{array}$ & $\begin{array}{c}0.678 \\
(28.613)^{* * *}\end{array}$ \\
\hline DISTANCE & $\begin{array}{c}-1.585 \\
(-16.350) * * *\end{array}$ & $\begin{array}{c}-1.414 \\
(-15.085) * * *\end{array}$ & $\begin{array}{c}-1.347 \\
(-13.860) * * *\end{array}$ & $\begin{array}{c}-1.398 \\
(-15.890) * * *\end{array}$ & $\begin{array}{c}-0.966 \\
(-10.668)^{* * *}\end{array}$ \\
\hline$D I F G D P P C$ & $\begin{array}{c}-0.446 \\
(-15.433)^{* * *}\end{array}$ & $\begin{array}{c}-0.227 \\
(-8.439)^{* * *}\end{array}$ & $\begin{array}{c}-0.057 \\
(-2.128)^{* *}\end{array}$ & $\begin{array}{l}-0.082 \\
(-3.141)^{* * *}\end{array}$ & $\begin{array}{c}-0.027 \\
(-0.947)\end{array}$ \\
\hline EXCHRATE & $\begin{array}{l}0.113 \\
(3.391)^{* * *}\end{array}$ & $\begin{array}{l}0.113 \\
(5.542)^{* * *}\end{array}$ & $\begin{array}{c}0.030 \\
(1.082)\end{array}$ & $\begin{array}{l}0.093 \\
(3.125)^{* * *}\end{array}$ & $\begin{array}{c}0.021 \\
(0.760)\end{array}$ \\
\hline FTADUMMY & $\begin{array}{l}0.614 \\
(4.112)^{* * *}\end{array}$ & $\begin{array}{l}0.257 \\
(2.475)^{* *}\end{array}$ & $\begin{array}{l}0.307 \\
(2.348)^{* *}\end{array}$ & $\begin{array}{l}0.298 \\
(2.184)^{* *}\end{array}$ & $\begin{array}{c}0.175 \\
(1.311)\end{array}$ \\
\hline Constant & $\begin{array}{l}2.142 \\
(1.986)^{* *}\end{array}$ & $\begin{array}{c}-3.864 \\
(-3.437)^{* * *}\end{array}$ & $\begin{array}{l}-5.386 \\
(-4.778)^{* * *}\end{array}$ & $\begin{array}{l}-6.432 \\
(-5.656)^{* * *}\end{array}$ & $\begin{array}{c}-11.672 \\
(-10.345)^{* * *}\end{array}$ \\
\hline No. of obs. & 1550 & 1760 & 1710 & 1770 & 1610 \\
\hline Wald-chi2 & 1167.608 & 1845.741 & 1455.236 & 1671.937 & 1459.592 \\
\hline loglikelihood & -12200.920 & -15736.002 & -11849.394 & -12000.255 & -11202.660 \\
\hline \multirow[t]{2}{*}{ Hausman } & -48.94 & $192.95 * * *$ & $82.94 * * *$ & 20.3 & $80.83 * * *$ \\
\hline & $\begin{array}{c}\text { Manuf. Goods } \\
\text { by Material }\end{array}$ & Leather & Ceramic & $\begin{array}{l}\text { Fabricated } \\
\text { Metal }\end{array}$ & Miscellaneous \\
\hline PARTRGDP & $\begin{array}{c}0.611 \\
(35.822)^{* * *}\end{array}$ & $\begin{array}{c}0.863 \\
(26.316)^{* * *}\end{array}$ & $\begin{array}{c}0.799 \\
(31.680)^{* * *}\end{array}$ & $\begin{array}{c}0.545 \\
(31.813)^{* * *}\end{array}$ & $\begin{array}{c}0.403 \\
(23.100)^{* * *}\end{array}$ \\
\hline DISTANCE & $\begin{array}{l}-0.856 \\
(-9.529)^{* * *}\end{array}$ & $\begin{array}{c}-1.474 \\
(-16.084)^{* * *}\end{array}$ & $\begin{array}{c}-1.068 \\
(-11.714)^{* * *}\end{array}$ & $\begin{array}{c}-1.164 \\
(-14.130)^{* * *}\end{array}$ & $\begin{array}{c}-1.268 \\
(-15.809)^{* * *}\end{array}$ \\
\hline$D I F G D P P C$ & $\begin{array}{l}-0.082 \\
(-3.646) * * *\end{array}$ & $\begin{array}{c}-0.068 \\
(-1.766)^{*}\end{array}$ & $\begin{array}{l}-0.141 \\
(-4.462) * * *\end{array}$ & $\begin{array}{l}-0.142 \\
(-6.634) * * *\end{array}$ & $\begin{array}{c}-0.334 \\
(-14.215)^{* * *}\end{array}$ \\
\hline EXCHRATE & $\begin{array}{l}0.102 \\
(5.981)^{* * *}\end{array}$ & $\begin{array}{l}0.087 \\
(2.759) * * *\end{array}$ & $\begin{array}{l}0.065 \\
(2.226)^{* *}\end{array}$ & $\begin{array}{l}0.069 \\
(3.754)^{* * *}\end{array}$ & $\begin{array}{l}0.160 \\
(6.531)^{* * *}\end{array}$ \\
\hline FTADUMMY & $\begin{array}{c}0.039 \\
(0.460)\end{array}$ & $\begin{array}{c}0.182 \\
(1.147)\end{array}$ & $\begin{array}{l}0.356 \\
(2.560)^{* *}\end{array}$ & $\begin{array}{c}0.029 \\
(0.310)\end{array}$ & $\begin{array}{c}0.121 \\
(0.988)\end{array}$ \\
\hline Constant & $\begin{array}{c}-9.457 \\
(-9.054) * * *\end{array}$ & $\begin{array}{l}-13.122 \\
(-9.537) * * *\end{array}$ & $\begin{array}{l}-14.599 \\
(-12.397)^{* * *}\end{array}$ & $\begin{array}{l}-4.505 \\
(-4.503) * * *\end{array}$ & $\begin{array}{c}0.079 \\
(0.084)\end{array}$ \\
\hline No. of obs. & 1900 & 1310 & 1570 & 1880 & 1760 \\
\hline Wald-chi2 & 2183.382 & 1334.524 & 1929.310 & 1884.060 & 1648.188 \\
\hline loglikelihood & -18115.906 & -7161.189 & -10516.528 & -18649.192 & -14931.381 \\
\hline Hausman & $118.68 * * *$ & $26.32 * *$ & $49.61 * * *$ & $152.22 * * *$ & $468.22 * * *$ \\
\hline
\end{tabular}

(Note) The numbers in parentheses are z-values. *,**, *** indicate significant level at 10\%, $5 \%$, and $1 \%$ respectively.

Negative binomial regression is tested using Stata command 'xtnbreg' with FE option.

Groups with all zero outcomes are dropped.

ble to the results for overall trade, are used for the regression, because sorted data includes many zero observations. Results of the estimation are listed in Tables 7 to 10. Key factors of the gravity model, PARTRGDP and DISTANCE, show expected and significant effects in all of the results for sorted export/import. These results indicate a validity of the gravity model.

With regard to Hypothesis 1, results of import (Tables 9 and 10) are comparable to overall 


\section{S. Maruyama}

Table 9: Import, Tobit regression: random effects

\begin{tabular}{|c|c|c|c|c|c|}
\hline & $\begin{array}{l}\text { Food and } \\
\text { Beverages }\end{array}$ & Textile & Apparel & $\begin{array}{l}\text { Lumber and } \\
\text { Furniture }\end{array}$ & $\begin{array}{l}\text { Paper and } \\
\text { Printing }\end{array}$ \\
\hline PARTRGDP & $\begin{array}{l}1.279 \\
(8.273)^{* * *}\end{array}$ & $\begin{array}{c}1.467 \\
(11.387)^{* * *}\end{array}$ & $\begin{array}{l}1.291 \\
(9.675)^{* * *}\end{array}$ & $\begin{array}{c}1.542 \\
(10.991)^{* * *}\end{array}$ & $\begin{array}{l}1.177 \\
(9.297)^{* * *}\end{array}$ \\
\hline DISTANCE & $\begin{array}{l}-2.113 \\
(-2.580) * * *\end{array}$ & $\begin{array}{l}-3.604 \\
(-5.269) * * *\end{array}$ & $\begin{array}{l}-3.773 \\
(-5.384) * * *\end{array}$ & $\begin{array}{l}-2.368 \\
(-3.184) * * *\end{array}$ & $\begin{array}{c}-2.656 \\
(-3.934) * * *\end{array}$ \\
\hline$D I F G D P P C$ & $\begin{array}{l}0.648 \\
(3.236) * * *\end{array}$ & $\begin{array}{c}0.916 \\
(5.540)^{* * *}\end{array}$ & $\begin{array}{l}0.688 \\
(4.080)^{* * *}\end{array}$ & $\begin{array}{l}0.925 \\
(5.077)^{* * * *}\end{array}$ & $\begin{array}{l}0.461 \\
(2.937)^{* * *}\end{array}$ \\
\hline EXCHRATE & $\begin{array}{r}0.015 \\
(0.170)\end{array}$ & $\begin{array}{l}0.178 \\
(2.842)^{* * *}\end{array}$ & $\begin{array}{r}0.064 \\
(0.922)\end{array}$ & $\begin{array}{c}0.128 \\
(1.710)^{*}\end{array}$ & $\begin{array}{l}0.170 \\
(3.009)^{* * *}\end{array}$ \\
\hline FTADUMMY & $\begin{array}{r}0.377 \\
(0.657)\end{array}$ & $\begin{array}{r}0.173 \\
(0.427)\end{array}$ & $\begin{array}{c}-0.188 \\
(-0.409)\end{array}$ & $\begin{array}{r}0.299 \\
(0.609)\end{array}$ & $\begin{array}{c}0.014 \\
(0.037)\end{array}$ \\
\hline Constant & $\begin{array}{c}-8.216 \\
(-0.901)\end{array}$ & $\begin{array}{c}-4.793 \\
(-0.630)\end{array}$ & $\begin{array}{r}4.554 \\
(0.582)\end{array}$ & $\begin{array}{l}-16.595 \\
(-2.003)^{* *}\end{array}$ & $\begin{array}{c}-5.924 \\
(-0.789)\end{array}$ \\
\hline No. of obs. & 1890 & 1890 & 1890 & 1890 & 1890 \\
\hline Wald-chi2 & 127.035 & 195.276 & 162.744 & 176.686 & 144.571 \\
\hline \multirow[t]{2}{*}{ loglikelihood } & -4762.192 & -4132.130 & -4349.848 & -4476.348 & -3959.787 \\
\hline & $\begin{array}{c}\text { Manuf. Goods } \\
\text { by Material }\end{array}$ & Leather & Ceramic & $\begin{array}{c}\text { Fabricated } \\
\text { Metal }\end{array}$ & Miscellaneous \\
\hline PARTRGDP & $\begin{array}{c}1.371 \\
(11.333)^{* * *}\end{array}$ & $\begin{array}{c}1.528 \\
(12.669)^{* * * *}\end{array}$ & $\begin{array}{c}1.254 \\
(12.494)^{* * * *}\end{array}$ & $\begin{array}{c}1.413 \\
(12.901)^{* * * *}\end{array}$ & $\begin{array}{c}1.473 \\
(12.503)^{* * *}\end{array}$ \\
\hline DISTANCE & $\begin{array}{l}-3.720 \\
(-5.876) * * *\end{array}$ & $\begin{array}{l}-2.928 \\
(-4.605) * * *\end{array}$ & $\begin{array}{l}-2.719 \\
(-5.146) * * *\end{array}$ & $\begin{array}{l}-3.857 \\
(-6.707) * * *\end{array}$ & $\begin{array}{l}-3.755 \\
(-6.056) * * *\end{array}$ \\
\hline$D I F G D P P C$ & $\begin{array}{r}0.178 \\
(1.104)\end{array}$ & $\begin{array}{l}0.596 \\
(3.780)^{* * *}\end{array}$ & $\begin{array}{l}0.330 \\
(2.434)^{* *}\end{array}$ & $\begin{array}{l}0.290 \\
(1.904)^{*}\end{array}$ & $\begin{array}{l}0.352 \\
(2.178)^{* *}\end{array}$ \\
\hline EXCHRATE & $\begin{array}{l}0.480 \\
(6.561)^{* * *}\end{array}$ & $\begin{array}{l}0.176 \\
(2.488)^{* *}\end{array}$ & $\begin{array}{l}0.181 \\
(2.851)^{* * *}\end{array}$ & $\begin{array}{l}0.155 \\
(2.122)^{* *}\end{array}$ & $\begin{array}{l}0.211 \\
(2.760)^{* * *}\end{array}$ \\
\hline FTADUMMY & $\begin{array}{r}0.379 \\
(0.784)\end{array}$ & $\begin{array}{r}0.580 \\
(1.235)\end{array}$ & $\begin{array}{r}0.634 \\
(1.505)\end{array}$ & $\begin{array}{c}-0.263 \\
(-0.542)\end{array}$ & $\begin{array}{c}0.953 \\
(1.879)^{*}\end{array}$ \\
\hline Constant & $\begin{array}{c}0.886 \\
(0.125)\end{array}$ & $\begin{array}{l}-11.729 \\
(-1.654)^{*}\end{array}$ & $\begin{array}{c}-7.590 \\
(-1.288)\end{array}$ & $\begin{array}{c}-0.018 \\
(-0.003)\end{array}$ & $\begin{array}{c}-1.856 \\
(-0.268)\end{array}$ \\
\hline No. of obs. & 1890 & 1890 & 1890 & 1890 & 1890 \\
\hline Wald-chi2 & 238.185 & 232.608 & 257.006 & 273.732 & 271.170 \\
\hline loglikelihood & -4421.914 & -4375.932 & -4157.5157 & -4415.631 & -4506.389 \\
\hline
\end{tabular}

(Note) The numbers in parentheses are $\mathrm{z}$-values. $*, * *, * *$ indicate significant level at $10 \%$, $5 \%$, and $1 \%$ respectively.

import (column 3 and 5 of Table 6). From the results using Tobit model, all coefficients of $D I F G D P P C$ are positive-signed and statistically significant. However, effect of income difference is smaller than that of overall import regarding four industrial groups. Especially, 'Manufacturing goods by material', 'Ceramic' and 'Fabricated metal' share a common feature of producing basic material. On the other hand, results using NB model with fixed effects are rather complicated; five groups with positive signs and five groups with negative signs. These results suggest that import of SME products as a whole tend to be larger with developing countries, while there are different impacts for each industrial group. 
Who causes SMEs to suffer? An empirical analysis on the trade of SME products in Japan

Table 10: Import, Negative binomial regression: fixed effects

\begin{tabular}{|c|c|c|c|c|c|}
\hline & $\begin{array}{l}\text { Food and } \\
\text { Beverages }\end{array}$ & Textile & Apparel & $\begin{array}{l}\text { Lumber and } \\
\text { Furniture }\end{array}$ & $\begin{array}{l}\text { Paper and } \\
\text { Printing }\end{array}$ \\
\hline PARTRGDP & $\begin{array}{c}0.557 \\
(25.922)^{* * *}\end{array}$ & $\begin{array}{c}1.144 \\
(35.242)^{* * *}\end{array}$ & $\begin{array}{c}0.587 \\
(26.571)^{* * *}\end{array}$ & $\begin{array}{c}0.714 \\
(29.322)^{* * *}\end{array}$ & $\begin{array}{c}0.856 \\
(20.434)^{* * *}\end{array}$ \\
\hline DISTANCE & $\begin{array}{l}-0.602 \\
(-6.828) * * *\end{array}$ & $\begin{array}{c}-1.388 \\
(-13.001)^{* * *}\end{array}$ & $\begin{array}{l}-0.847 \\
(-9.253) * * *\end{array}$ & $\begin{array}{l}-0.648 \\
(-6.392) * * *\end{array}$ & $\begin{array}{l}-1.037 \\
(-8.459) * * *\end{array}$ \\
\hline$D I F G D P P C$ & $\begin{array}{l}0.103 \\
(3.858)^{* * *}\end{array}$ & $\begin{array}{l}0.163 \\
(4.334)^{* * *}\end{array}$ & $\begin{array}{c}-0.047 \\
(-1.770)^{*}\end{array}$ & $\begin{array}{l}0.160 \\
(5.488)^{* * *}\end{array}$ & $\begin{array}{l}-0.228 \\
(-5.189)^{* * *}\end{array}$ \\
\hline EXCHRATE & $\begin{array}{r}0.028 \\
(0.920)\end{array}$ & $\begin{array}{l}0.120 \\
(5.930)^{* * *}\end{array}$ & $\begin{array}{l}0.057 \\
(2.082)^{* *}\end{array}$ & $\begin{array}{l}0.097 \\
(3.081)^{* * *}\end{array}$ & $\begin{array}{l}0.197 \\
(4.989)^{* * *}\end{array}$ \\
\hline FTADUMMY & $\begin{array}{l}0.288 \\
(1.979)^{* *}\end{array}$ & $\begin{array}{l}0.248 \\
(2.149)^{* *}\end{array}$ & $\begin{array}{l}0.299 \\
(2.207)^{* *}\end{array}$ & $\begin{array}{l}0.507 \\
(3.428)^{* * *}\end{array}$ & $\begin{array}{c}0.343 \\
(1.943)^{*}\end{array}$ \\
\hline Constant & $\begin{array}{c}-11.311 \\
(-11.657)^{* * *}\end{array}$ & $\begin{array}{l}-22.027 \\
(-17.277)^{* * *}\end{array}$ & $\begin{array}{l}-9.593 \\
(-8.582)^{* * *}\end{array}$ & $\begin{array}{c}-16.112 \\
(-14.006)^{* * *}\end{array}$ & $\begin{array}{l}-16.959 \\
(-9.541) * * *\end{array}$ \\
\hline No. of obs. & 1700 & 1240 & 1730 & 1650 & 900 \\
\hline Wald-chi2 & 835.271 & 1723.949 & 1159.589 & 1082.092 & 660.448 \\
\hline loglikelihood & -18016.163 & -9768.968 & -15203.221 & -13439.827 & -6963.796 \\
\hline \multirow[t]{2}{*}{ Hausman } & 7.31 & 7.81 & $193.06 * * *$ & -116.29 & $25.58 * *$ \\
\hline & $\begin{array}{c}\text { Manuf. Goods } \\
\text { by Material }\end{array}$ & Leather & Ceramic & $\begin{array}{l}\text { Fabricated } \\
\text { Metal }\end{array}$ & Miscellaneous \\
\hline PARTRGDP & $\begin{array}{c}0.691 \\
(29.433)^{* * *}\end{array}$ & $\begin{array}{c}0.730 \\
(26.519)^{* * *}\end{array}$ & $\begin{array}{c}1.090 \\
(24.277)^{* * *}\end{array}$ & $\begin{array}{c}0.898 \\
(30.066)^{* * *}\end{array}$ & $\begin{array}{c}0.729 \\
(25.428) * * *\end{array}$ \\
\hline DISTANCE & $\begin{array}{c}-1.601 \\
(-15.976)^{* * *}\end{array}$ & $\begin{array}{l}-0.598 \\
(-6.269)^{* * *}\end{array}$ & $\begin{array}{c}-1.066 \\
(-8.226)^{* * *}\end{array}$ & $\begin{array}{c}-1.801 \\
(-15.018)^{* * *}\end{array}$ & $\begin{array}{c}-1.182 \\
(-12.290) * * *\end{array}$ \\
\hline$D I F G D P P C$ & $\begin{array}{l}-0.322 \\
(-9.420) * * *\end{array}$ & $\begin{array}{r}0.007 \\
(0.217)\end{array}$ & $\begin{array}{l}0.105 \\
(2.228)^{* *}\end{array}$ & $\begin{array}{r}-0.055 \\
(-1.533)\end{array}$ & $\begin{array}{c}-0.081 \\
(-2.352) * *\end{array}$ \\
\hline EXCHRATE & $\begin{array}{l}0.165 \\
(6.629)^{* * *}\end{array}$ & $\begin{array}{l}0.131 \\
(4.161)^{* * *}\end{array}$ & $\begin{array}{l}0.079 \\
(2.333)^{* *}\end{array}$ & $\begin{array}{l}0.135 \\
(4.984)^{* * *}\end{array}$ & $\begin{array}{l}0.102 \\
(3.386)^{* * *}\end{array}$ \\
\hline FTADUMMY & $\begin{array}{l}0.467 \\
(3.564)^{* * *}\end{array}$ & $\begin{array}{l}0.409 \\
(2.707) * * *\end{array}$ & $\begin{array}{l}0.392 \\
(2.371)^{* *}\end{array}$ & $\begin{array}{l}0.288 \\
(1.999)^{* *}\end{array}$ & $\begin{array}{l}0.506 \\
(3.498)^{* * *}\end{array}$ \\
\hline Constant & $\begin{array}{c}-5.847 \\
(-4.868) * * *\end{array}$ & $\begin{array}{l}-16.867 \\
(-13.587)^{* * *}\end{array}$ & $\begin{array}{l}-24.159 \\
(-13.091)^{* * *}\end{array}$ & $\begin{array}{l}-10.996 \\
(-8.527) * * *\end{array}$ & $\begin{array}{l}-11.319 \\
(-9.243)^{* * *}\end{array}$ \\
\hline No. of obs. & 1360 & 1420 & 1010 & 1360 & 1530 \\
\hline Wald-chi2 & 1811.732 & 1087.600 & 899.450 & 1250.966 & 1305.706 \\
\hline loglikelihood & -11031.814 & -11614.340 & -6810.704 & -9404.643 & -11450.312 \\
\hline Hausman & 3.69 & -349.04 & $50.75 * * *$ & $72.45 * * *$ & $35.09 * *$ \\
\hline
\end{tabular}

(Note) The numbers in parentheses are z-values. *,**, *** indicate significant level at 10\%, $5 \%$, and $1 \%$ respectively.

Negative binomial regression is tested using Stata command 'xtnbreg' with FE option.

Groups with all zero outcomes are dropped.

With regard to Hypothesis 2, a negative and significant result of overall export (column 3 of Table 5) is comparable to the results of sorted export using Tobit model (Table 7). All of the coefficients of DISTANCE are negative-signed and have a larger effect than overall export. Meanwhile, signs of DISTANCE are all negative but magnitude of effect varies for different methods. Under Tobit regression, all industrial groups but 'Food and Beverages' indi- 


\section{S. Maruyama}

cate larger effect. Using NB model with fixed effects, only three industrial groups of 'Textile', 'Manufacturing goods by material' and 'Fabricated metal' show larger effect than overall import.

From these estimated results, it is obvious that the key gravity factors explain the trade flow. However, the effects of determinants vary among each industrial group. We need to do further study looking at the relationship with industrial characteristics.

\section{Concluding remarks}

This paper investigates the structure and the determinants of trade of SME products using the trade database prepared for selected SME-based industries. The main findings of this paper are summarized as follows. Firstly, the estimated trade value for SME products shows that firms in SME-based industries are facing a large inflow of imported goods, while the volume of their export is relatively small. In a third of SME-based industries, import exceeds domestic production. Secondly, the share of Asian countries in SME products is larger than those shares in overall trade. Thirdly, the gravity model explains the trade flow of SME products. For aggregated trade of SME products, the susceptibility to the distance and the difference of income level is consistent with the labor-intensive character of SME products. Meanwhile, estimation results depend on the methods in some degree. Further investigation is necessary to assess the country-specific and industrial characteristics.

The results from our analysis suggest that SMEs in Japan are facing a severe situation in competing with products from developing countries in the domestic market. This paper focuses on the trade during 2001-2010, however, the results should be interpreted in the context of a long-term change of industrial and trade structure since the 1980s in Japan and the world economy. It illustrates a consequence of the changes of circumstances for Japanese SMEs. Further research is necessary to examine quantitatively whether the trade has affect for SMEs concerning their domestic production, employment, and entry/exit.

\section{References}

Ahn, J.B., A.K. Khandelwal and S.J. Wei (2011), “The role of intermediaries in facilitating trade,” Journal of International Economics vol. 84, pp. 73-85.

Baldwin, R. and J. Harrigan (2011), "Zeros, quality, and space: trade theory and trade evidence," American Economic Journal: Microeconomics, vol. 3, no. 2, pp. 60-88.

Bernard, A.B., M. Grazzi and C. Tomasi (2011), "Intermediaries in international trade: direct versus indirect modes of export," NBER Worikng Paper Series No. 17711.

Cameron, A.C. and P.K. Trivedi (1998), Regression Analysis of Count Data, Cambridge University Press.

Cameron, A.C. and P.K. Trivedi (2005), Microeconometrics: Methods and Applications, Cambridge University Press.

Coviello, N.E. and A. McAuley (1999), "Internationalisation and the smaller firm: a review of contemporary empirical research,” Management International Review, vol. 39, no. 3, pp. 223-256.

Dicken, P. (2011), Global Shift 6th edition, SAGE.

Doi, N. (1992), "The efficiency of small manufacturing firms in Japan,” Small Business Economics, vol. 4, pp. 29-35.

Dunning, J.H. (1977), "Trade, location of economic activities and the MNE: A search for an eclectic 
Who causes SMEs to suffer? An empirical analysis on the trade of SME products in Japan

approach," In: Ohlin, B., P.-O. Hesselborn and P.M. Wijkman (eds.) The International Allocation of Economic Activity, MacMillan.

Feenstra, R.C. (1996), “U.S. imports, 1972-1994: data and concordances,” NBER Working Paper Series No. 5515.

Feenstra, R.C. (2016), Advanced International Trade: Theory andEvidence, Second edition, Princeton University Press.

Feenstra, R.C., J. Romalis and P.K. Schott (2002), “U.S. imports, exports and tariff data, 1989-2001,” NBER Working Paper Series No.9387.

Freeman, R.B. and L.F. Katz (1991), "Industrial wage and employment determination in an open economy," In: Abowd, J.M. and R.B. Freeman (eds.) Immigration, Trade and the Labor Market, The University of Chicago Press.

Hollenstein, H. (2005), "Determinants of international activities: are SMEs different ?," Small Business Economics, vol. 24, pp. 431-450.

Honjo, Y. and N. Harada (2006), "SME policy, financial structure and firm growth: evidence from Japan," SmallBusinessEconomics, vol. 27, pp. 289-300.

Hummels, D. and A. Skiba (2004), "Shipping the good apples out? An empirical confirmation of the Alchian-Allen conjecture," Journal of Political Economy, vol. 112, no. 6, pp. 1384-1402.

Linnemann, H. (1966), An Econometric Study of International Trade Flows. North-Holland.

Kawai, H. (2004), "Chusho kigyou no global-ka no shinten: sono youin to seika," RIETI Discussion Paper Series 04-J-037 (in Japanese).

Kawai, H. and S. Urata (2002), "Entry of small and medium enterprises and economic dynamism in Japan," SmallBusinessEconomics, vol. 18, pp. 41-51.

Sachs, J.D. and H.J. Shatz (1994), "Trade and jobs in U.S. manufacturing," Brookings Papers on Economic Activity, vol. 1, pp. 1-84.

Small and Medium Enterprise Agency (ed.) (2002), White Paper on Small and Medium Enterprises in Japan 2002, Japan Small Business Research Institute.

Small and Medium Enterprise Agency (ed.) (2006), White Paper on Small and Medium Enterprises in Japan 2006, Japan Small Business Research Institute.

Small and Medium Enterprise Agency (ed.) (2012), White Paper on Small and Medium Enterprises in Japan 2012, Japan Small Business Research Institute.

Stack, M.M. (2009), "Regional integration and trade: controlling for varying degrees of heterogeneity in the gravity model," The World Economy, vol. 32, no. 5, pp. 772-789.

Tinbergen, J. (1962), Shaping the World Economy: Suggestions for an International Economic Policy. The Twentieth Century Fund.

Todo, Y. (2012), "Nihon no chusho kigyou no kaigai seisan itaku," RIETI Discussion Paper Series 12-J-004 (in Japanese).

Tomiura, E. (2003), "The impact of import competition on Japanese manufacturing employment," Journal of The Japanese and International Economies, vol. 17, pp. 118-133.

Tomiura, E. (2004), "Import competition and employment in Japan: plant startup, shutdown and product changes," The Japanese Economic Review, vol. 55, no. 2, pp. 141-152.

Tomiura, E. and Y. Uchida (2001), "The Impact of import competition on gross job creation and destruction: a study based on Japanese import-industry data concordance," METI/RI Discussion Paper Series 01-DOF-36.

Urata, S. and H. Kawai (2000), "The determinants of the location of foreign direct investment by Japanese small and medium-sized enterprises," Small Business Economics, vol. 15, no. 2, pp. 79-103. 